\title{
PENGARUH MODEL PEMBELAJARAN KOOPERATIF NHT (NUMBERED HEAD TOGETHER) BERBANTUAN MIND MAPPING TERHADAP HASIL BELAJAR FISIKA PADA MATERI POKOK LISTRIK DINAMIS
}

\author{
Oleh: \\ Dede Parsaoran Damanik ${ }^{1)}$ \\ Jelita Panjaitan ${ }^{2)}$ \\ dan Ika Trisni Simangunsong ${ }^{3)}$ \\ Universitas Darma Agung, Medan 1,2,3) \\ E-mail: \\ dedeparsaoran@gmail.com ${ }^{1)}$ \\ jelitapanjaitan3@gmail.com ${ }^{2)}$ \\ dan ikatrisnisimangunsong@ gmail.com ${ }^{3)}$
}

\begin{abstract}
This study aims at determining the significant influence of the NHT (Numbered Head Together) Cooperative Learning Model assisted by Mind Mapping on physics learning outcomes in the dynamic electric subject matter of class XII semester I students of SMK YAPIM TARUNA Sei Rotan. This type of research is a quasi experiment. The population in this study is all students of class XII SMK IAP YAPIM TARUNA. Sampling was done by cluster random sampling technique, then obtained class XII-1 $=35$ people as an experimental class taught using the NHT (Numbered Head Together) Cooperative Learning model assisted by Mind Mapping and class XII-2 = 35 people as control classes taught by the Direct Learning model. This research instrument consisted of 25 multiple choice questions with 5 options (a, b, c, d, and e) which had previously been tested to determine the validity, reliability, level of difficulty and distinguishing power of the test. From the results of the study, an average value of experimental class pretest of 32.18 with a standard deviation of 9.49 and an average value of pretest of 31.18 with a standard deviation of 10.96 was obtained. From the results of the two-party t test obtained $t_{\text {count }}=0.49$ and $\mathrm{t}_{\text {table }}=1.99$, because $\mathrm{t}_{\text {count }}<\mathrm{t}_{\text {table }}(0.49<1.99)$ this shows that the initial ability of the two classes is the same. Then a different treatment was given. After the learning ended, posttest was done with the average value of the experimental class 73.18 with a standard deviation of 10.37 and the average value of the Control class 56.54 with a standard deviation of 11.94. The results of one-party $\mathrm{t}$ test obtained the price of $\mathrm{t}_{\text {count }}=7.44$ and $\mathrm{t}_{\text {table }}=1.67$ at the significant level $\alpha=$ 0.05 and $\mathrm{dk}=86$, because $\mathrm{t}_{\text {count }}>\mathrm{t}_{\text {table }}(7.44>1.67)$, this shows that there is a significant influence significant NHT (Numbered Head Together) Cooperative learning model aided by Mind Mapping on physics learning outcomes on the subject matter of Dynamic Electricity.
\end{abstract}

Keywords: NHT Assisted Cooperative Model Mind Mapping, Learning Outcomes, Dynamic Electricity

\begin{abstract}
ABSTRAK
Penelitian ini bertujuan untuk mengetahui pengaruh yang signifikan Model Pembelajaran Kooperatif NHT (Numbered Head Together) berbantuan Mind Mapping terhadap hasil belajar fisika pada materi pokok listrik dinamis siswa kelas XII semester I SMK YAPIM TARUNA Sei Rotan. Jenis penelitian ini adalah quasi eksperiment (eksperimen semu). Populasi dalam penelitian ini adalah seluruh siswa kelas XII SMK semester I SMK YAPIM TARUNA. Pengambilan sampel dilakukan dengan teknik acak kelas (cluster random sampling), maka diperoleh kelas XII-1 = 35 orang sebagai kelas eksperimen yang diajar dengan menggunakan model Pembelajaran Kooperatif NHT (Numbered Head Together) berbantuan Mind Mapping dan kelas XII-2 $=35$ orang sebagai kelas kontrol yang diajar dengan model Pembelajaran Langsung. Instrumen penelitian ini berjumlah 25 butir soal berbentuk pilihan ganda dengan 5
\end{abstract}


option (a, b, c, d, dan e) yang sebelumnya telah diuji cobakan untuk mengetahui validitas, reliabilitas, tingkat kesukaran dan daya pembeda tes. Dari hasil penelitian diperoleh nilai ratarata pretes kelas eksperimen sebesar 32,18 dengan standar deviasi 9,49 dan nilai rata-rata pretes sebesar 31,18 dengan standar deviasi 10,96. Dari hasil uji $\mathrm{t}$ dua pihak diperoleh $\mathrm{t}_{\text {hitung }}=0,49$ dan $t_{\text {tabel }}=1,99$, karena $t_{\text {hitung }}<t_{\text {tabel }}(0,49<1,99)$ hal ini menunjukkan bahwa kemampuan awal kedua kelas adalah sama. Kemudian diberi perlakuan yang berbeda. Setelah pembelajaran berakhir dilakukan postes dengan hasil nilai rata - rata kelas eksperimen 73,18 dengan standar deviasi 10,37 dan nilai rata- rata kelas Kontrol 56,54 dengan standar deviasi 11,94. Hasil uji t satu pihak diperoleh harga $\mathrm{t}_{\text {hitung }}=7,44$ dan $\mathrm{t}_{\text {tabel }}=1,67$ pada taraf signifikan $\alpha=0.05$ dan $\mathrm{dk}=86$, karena $t_{\text {hitung }}>t_{\text {tabel }}(7,44>1,67)$, hal ini menunjukkan bahwa ada pengaruh yang signifikan model pembelajaran Kooperatif NHT (Numbered Head Together) berbantuan Mind Mapping terhadap hasil belajar fisika pada materi pokok Listrik Dinamis.

\section{Kata kunci: Model Kooperatif NHT Berbantuan Mind Mapping, Hasil Belajar, Listrik Dinamis}

\section{PENDAHULUAN}

Kemajuan suatu bangsa sangat ditentukan oleh kualitas sumber daya manusia (SDM). Kualitas sumber daya manusia sangat bergantung pada kualitas pendidikan. Pendidikan memegang peranan penting dalam pembangunan bangsa karena pendidikan sebagai akar pembangunan bangsa. Berhasilnya pembangunan di bidang pendidikan akan sangat berpengaruh terhadap pembangunan di bidang yang lainnya. Oleh karena itu, pembangunan dalam bidang pendidikan sekarang ini semakin giat dilaksanakan. Berbagai cara pun ditempuh untuk memperoleh pendidikan baik pendidikan secara formal maupun pendidikan secara non formal.

Berkembangnya pendidikan sudah pasti berpengaruh terhadap perkembangan ilmu pengetahuan dan teknologi (IPTEK). Hal ini dapat terlihat dengan semakin pesatnya perkembangan ilmu pengetahuam dan teknologi sekarang ini yang tidak terlepas dari kemajuan ilmu fisika yang banyak menghasilkan temuan baru dalam bidang sains dan teknologi.Agar tujuan tersebut dapat tercapai,maka dalam proses pembelajarannya dituntut agar siswa berperan aktif dalam pembelajaran

Fisika pada umumnya adalah ilmu pengetahuan alam yang cukup menarik, Karena mempelajari bagian - bagian dari alam dan interaksi di dalamnya serta dapat diterangkan dengan konsep - konsep sederhana. Namun pada kenyataan dari pengalaman peneliti pada saat PPL (Praktek Pengalaman Lapangan) di SMK Negeri 1
Lubuk Pakam banyak siswa yang menganggap mata pelajaran Fisika merupakan mata pelajaran yang sangat sulit, sehingga siswa terlebih dahulu merasa kurang mampu dan merasa bosan dalam mempelajarinya. Akibatnya masih banyak siswa mendapat nilai Fisika yang sangat rendah dibandingkan dengan mata pelajaran yang lain.

Berbagai upaya telah dilakukan oleh pemerintah dalam meningkatkan mutu pendidikan fisika di Indonesia, namun sampai saat ini belum memperoleh hasil yang optimal. Adapun faktor yang menyebabkan rendahnya hasil belajar siswa berdasarkan hasil observasi dan wawancara guru fisika di SMK YAPIM TARUNA Sei Rotan yang menyatakan bahwa rendahnya hasil belajar siswa disebabkan oleh rendahnya minat belajar siswa, siswa kurang termotivasi, ada pun model pembelajaran Fisika kurang bervariasi. Dalam pembelajaran Fisika lebih dominan menggunakan model pembelajaran langsung. Dalam proses pembelajaran guru menjelaskan materi, menjelaskan rumus, memberi contoh soal dan memberikan PR, sehingga siswa dalam pembelajaran menjadi penerima informasi pasif. Siswa yang lebih banyak belajar dengan menghafal, menulis. Hal ini membuat siswa kurang tertarik pada pelajaran fisika, sehingga hasil belajar siswa yang di peroleh tidak maksimal.

Salah satunya dengan cara mengembangkan model pembelajaran kooperatif NHT (Numberd Head Together). Teknik belajar mengajar ini dikembangkan oleh Spenser Kagen (1993), teknik ini 
memberi kesempatan kepada siswa untuk saling membagikan ide-ide dan mempertimbangkan jawaban yang paling tepat. Selain itu, teknik ini juga mendorong siswa untuk meningkatkan semangat kerja sama mereka. Dengan terbentuknya diskusi dalam kelompok belajar kooperatif NHT (Numbered Head Together) diharapkan dapat menumbuhkan dan mengembangkan rasa sosial yang tinggi pada diri setiap anak. Karena mereka dibina untuk mengendalikan rasa egois yang ada dalam diri masingmasing sehingga terbina kesetiakawanan sosial. Persaingan positif terjadi antara siswa di kelas dalam rangka pencapaian prestasi belajar yang optimal. Inilah yang di harapkan yakni anak didik yang aktif, kreatif, dan mandiri.

\section{TINJAUAN PUSTAKA}

Beberapa hasil penelitian terdahulu telah dilakukan terkait dengan model pembelajaran kooperatif NHT (Numbered Head Together). Juniar (2014) melakukan penelitian dengan menggunakan model pembelajaran kooperatif tipe NHT dengan menggunakan media mind mapping menunjukkan bahwa nilai rata-rata siswa dikelas eksperimen meningkat dari 43,5 menjadi 76,02. Sementara Rahmad, dkk (2013) melakukan penelitian dengan menggunakan model pembelajaran kooperatif tipe NHT berbantuan handout menunjukkan bahwa nilai rata-rata hasil belajar kelas eksperimen lebih tinggi dibandingkan dengan kelas control yang berbeda secara signifikan. Nilai rata-rata kelas eksperimen untuk aspek kognitif adalah 83,75 dan pada kelas kontrol 69,14.

Siswanto (2015) melakukan penelitian dengan menggunakan model pembelajaran kooperatif tipe NHT dengan media LKS menunjukkan bahwa nilai rata-rata siswa dikelas eksperimen meningkat dari 80,55\% menjadi $88,88 \%$. Penelitian yang dilakukan oleh Anggita \& Suliyanah (2012) yang menggunakan model pembelajaran kooperatif tipe NHT dengan metode snowball menunjukkan bahwa sangat berpengaruh positif terhadap hasil belajar siswa. Kemudian Karmila, dkk melakukan penelitian dengan menggunakan model pembelajaran kooperatif tipe NHT dengan pendekatan CTL menunjukkan nilai rata-rata siswa di kelas eksperimen meningkat dari 5,33 menjadi 10,13.

Berdasarkan uraian di atas penulis tertarik untuk mengangkat permasalahan ini menjadi suatu penelitian dengan judul "Pengaruh Model Pembelajaran Kooperatif NHT (Numbered Head Together) Berbantuan Mind Mapping Terhadap Hasil Belajar Fisika Pada Materi Pokok Listrik Dinamis".

Numbered Head Together (NHT) adalah merupakan jenis pembelajaran kooperatif yang di rancang untuk memengaruhi pola interaksi siswa dan sebagai alternatif terhadap struktur kelas tradisional (Trianto 2009:82).Type ini di kembangkan oleh Spenser Kagen dengan melibatkan para siswa dalam menelaah bahan yang tercakup dalam suatu pelajaran dan mengecek pemahaman mereka terhadap isi pelajaran tersebut. Menurut Shoimin (2014:108) "Numbered Head Together merupakan suatu model pembelajaran berkelompok yang setiap anggota kelompoknya bertanggung jawab atas tugas kelompoknya".

Langkah - langkah pembelajaran kooperatif tipe NHT tersebut disajikan dalam tujuh tahap seperti tabel 2.1:

Tabel 1. Langkah-langkah model pembelajaran kooperatif tipe NHT

\begin{tabular}{|ll|lr|}
\hline \multicolumn{2}{|c|}{ Fase } & \multicolumn{2}{|c|}{ Peran Guru } \\
\hline 1. & Penomoran & $\begin{array}{l}\text { Guru membagi } \\
\text { siswa kedalam } \\
\text { kelompok 5 orang } \\
\text { dan kepada setiap } \\
\text { anggota kelompok } \\
\text { diberi nomor antara } \\
\text { 1 sampai 5 }\end{array}$ \\
\hline $\begin{array}{l}\text { nengajuka } \\
\text { pertanyaan }\end{array}$ & $\begin{array}{l}\text { Guru mengajukan } \\
\text { sebuah pertanyaan } \\
\text { kepada } \\
\text { pertanyaan diswa } \\
\text { bervariasi }\end{array}$ \\
\hline 3. & $\begin{array}{l}\text { Berpikir } \\
\text { bersama }\end{array}$ & $\begin{array}{l}\text { Guru menyuruh } \\
\text { kerja sama siswa. } \\
\text { Siswa disuruh } \\
\text { keluar }\end{array}$ \\
&
\end{tabular}




\begin{tabular}{|c|c|}
\hline & $\begin{array}{l}\text { kelompoknya dan } \\
\text { bergabung bersama } \\
\text { beberapa siswa } \\
\text { bernomor sama dari } \\
\text { kelompok lain. }\end{array}$ \\
\hline 4. Menjawab & $\begin{array}{lr}\text { Guru } & \text { memanggil } \\
\text { suatu } & \text { nomor } \\
\text { tertentu, } & \text { kemudian } \\
\text { siswa } & \text { yang } \\
\text { nomornya } & \text { dipanggil } \\
\text { mencoba } & \text { untuk } \\
\text { menjawab } & \\
\text { pertanyaan } & \text { untuk } \\
\text { seluruh kelas } & \end{array}$ \\
\hline
\end{tabular}

Menurut Imas \& Berlin (2015:53) mind mapping merupakan cara untuk menempatkan informasi kedalam otak dan mengambilnya kembali keluar otak.

Mind mapping dapat disebut sebuah peta rute yang digunakan ingatan, membuat kita bisa menyusun fakta dan pikiran sedemikian rupa sehingga cara kerja otak kita yang alami akan dilibatkan sejak awal sehingga mengingat informasi akan lebih mudah dan bisa diandalkan daripada menggunakan teknik mencatat biasa.

Trianto (2009:41) Pembelajaran Langsung adalah suatu model pengajaran yang bersifat teacher center. Selain itu model pembelajaran langsung ditujukan pula untuk membantu siswa mempelajari keterampilan dasar dan memperoleh informasi yang dapat diajarkan selangkah demi selangkah.

Pada model pengajaran langsung terdapat lima fase yang sangat penting. Guru mengawali pelajaran dengan penjelasan tentang tujuan dan latar belakang pembelajaran, serta mempersiapkan siswa untuk menerima penjelasan guru. Sintaks model pembelajaran langsung tersebut disajikan dalam lima tahap seperti tabel 2:

Tabel 2. Sintaks Model Pembelajaran Langsung

\begin{tabular}{|c|c|}
\hline Fase & Peran guru \\
\hline $\begin{array}{l}\text { 1. Menyampaika } \\
\text { n tujuan dan } \\
\text { mempersiapka } \\
\text { n siswa }\end{array}$ & $\begin{array}{l}\text { Guru menjelaskan TPK, } \\
\text { informasi latar belakang } \\
\text { pelajaran, pentingnya } \\
\text { pelajaran, mempersiapkan } \\
\text { siswa untuk belajar }\end{array}$ \\
\hline
\end{tabular}

\begin{tabular}{|c|c|c|}
\hline & $\begin{array}{l}\text { Mendemonstr } \\
\text { asikan } \\
\text { pengetahuan } \\
\text { dan } \\
\text { keterampilan }\end{array}$ & $\begin{array}{l}\text { Guru mendemonstrasikan } \\
\text { keterampilan } \\
\text { benar, atau menyajikan } \\
\text { informasi tahap demi } \\
\text { tahap. }\end{array}$ \\
\hline 3. & $\begin{array}{l}\text { Membimbing } \\
\text { pelatihan }\end{array}$ & $\begin{array}{l}\text { Guru merencanakan dan } \\
\text { memberikan bimbingan } \\
\text { pelatihan awal. }\end{array}$ \\
\hline 4. & $\begin{array}{l}\text { Mengecek } \\
\text { pemahaman } \\
\text { dan } \\
\text { memberikan } \\
\text { umpan balik }\end{array}$ & $\begin{array}{l}\text { Mencek apakah siswa telah } \\
\text { berhasil melakukan tugas } \\
\text { dengan baik, memberi } \\
\text { umpan balik. }\end{array}$ \\
\hline 5. & $\begin{array}{l}\text { Memberikan } \\
\text { kesempatan } \\
\text { untuk } \\
\text { pelatihan } \\
\text { lajutan dan } \\
\text { penerapan }\end{array}$ & $\begin{array}{l}\text { Guru mempersiapkan } \\
\text { kesempatan melakukan } \\
\text { pelatihan lanjutan, dengan } \\
\text { perhatian khusus pada } \\
\text { penerapan kepada situasi } \\
\text { lebih kompleks dan } \\
\text { kehidupan sehari-hari. }\end{array}$ \\
\hline
\end{tabular}

Untuk mencapai hasil belajar yang baik guru harus mampu memilih dan menerapkan model pembelajaran yang sesuai dengan materi pelajaran, kemampuan siswa dan tujuan pembelajaran yang telah ditetapkan. Guru juga harus melibatkan siswa untuk aktif dalam proses belajar mengajar dan menciptakan suasana belajar yang nyaman, tidak monoton dan memberikan kebebasan pada siswa untuk berinteraksi dan berpendapat.

Model pembelajaran kooperatif NHT (Numbered Head Together) merupakan salah satu model pembelajaran yang mendorong siswa untuk berperan lebih aktif dalam proses belajar mengajar sehingga siswa lebih mudah memahami konsep materi yang dipelajari.

Model pembelajaran kooperatif NHT (Numbered Head Together) dapat memacu proses berpikir siswa secara kritis dan analitis untuk mengetahui, menemukan jawaban dan memecahkan masalahnya sendiri. Model pembelajaran kooperatif NHT (Numbered Head Together) berorientasi pada siswa, sebab dalam model ini siswa tidak lagi berperan sebagai penerima informasi pasif yang hanya menerima materi pelajaran melalui penjelasan guru secara verbal. Tetapi siswa untuk lebih aktif berpikir menemukan sendiri inti dari materi pelajaran sehingga siswa lebih mudah memahami konsep materi yang dipelajari. Guru hanya berperan 
sebagai fasilitator, motivator, penanya, administrator, dan memberi pengaruh terhadap perkembangan belajar siswa.

Dengan menggunakan model pembelajaran kooperatif NHT (Numbered Head Together) berbantuan Mind Mapping diharapkan siswa dapat memahami konsepkonsep fisika dengan baik melalui pengalaman-pengalaman belajar yang aktif karena siswa belajar memecahkan masalah secara mandiri dan memiliki keterampilan berpikir kritis sehingga tingkat keberhasilan belajar siswa dapat meningkat.

Untuk mengetahui pengaruh model pembelajaran kooperatif NHT (Numbered Head Together) berbantuan Mind Mapping terhadap hasil belajar siswa maka dilakukan uji hipotesis. Uji hipotesis yang digunakan adalah uji t dua pihak dan uji t satu pihak. Uji $t$ dua pihak digunakan pada saat menganalisa data pretes untuk mengetahui kemampuan awal siswa pada kedua kelompok sampel. Uji $t$ satu pihak digunakan pada saat menganalisa data postes untuk mengetahui pengaruh perlakuan yaitu model pembelajaran kooperatif NHT (Numbered Head Together) berbantuan Mind Mapping terhadap hasil belajar siswa. Analisis statistik dilakukan dengan membandingkan hasil belajar siswa pada kelas eksperimen yang menggunakan model pembelajaran kooperatif NHT (Numbered Head Together) berbantuan Mind Mapping dengan hasil belajar siswa pada kelas kontrol yang menggunakan model pembelajaran langsung. Jika analisis statistik menunjukkan hasil belajar siswa pada kelas ekperimen lebih baik dari pada hasil belajar siswa pada kelas kontrol maka dapat dikatakan model pembelajaran kooperatif NHT (Numbered Head Together) berbantuan Mind Mapping mempengaruhi hasil belajar siswa. Adapun yang menjadi hipotesis dalam penelitian ini apakah ada pengaruh yang signifikan model pembelajaran kooperatif NHT (Numbered Head Together) berbantuan Mind Mapping terhadap hasil belajar fisika pada materi pokok Listrik Dinamis siswa kelas atau tidak ada pengaruh yang signifikan model pembelajaran kooperatif NHT (Numbered Head Together) berbantuan Mind Mapping terhadap hasil belajar fisika pada materi pokok Listrik Dinamis.

\section{METODE PELAKSANAAN}

Penelitian ini adalah penelitian quasi eksperimen. Populasi penelitian ini adalah seluruh siswa kelas XII XMK YAPIM TARUNA Sei Rotan yang terdiri dari 4 Kelas. Sampel penelitian dilakukan dengan cara tehnik acak kelas (cluster random sampling) sebanyak dua kelas. Dimana kelas pertama dijadikan kelas eksperimen (kelas XII-1) dengan menggunakan model Kooperatif NHT Berbantuan Mind Mapping dan kelas kedua dijadikan kelas kontrol (kelas XII -2 ) dengan pembelajaran Direct Intruction. Jumlah siswa masing-masing tiap kelas 35 orang.

Peneliti melakukan tes untuk mengetahui hasil belajar fisika siswa pada kedua kelas sebelum dan sesudah diberikan perlakuan. Desain penelitian yang digunakan desain two group pretest-posttest design.

Data yang diperoleh ditabulasikan kemudian dicari rata-ratanya. Sebelum dilakukan analisis data, terlebih dahulu ditentukan nilai masing-masing kelompok sampel lalu dilakukan pengolahan data dengan langkah-langkah sebagai berikut yakni : menghitung nilai rata-rata dan simpangan baku, uji normalitas menggunakan uji Lilliefors, uji homogenitas menggunakan uji $\mathrm{F}$, pengujian kesamaan rata-rata pretes menggunakan uji $t$ dua pihak dan pengujian hipotesis menggunakan uji $t$ satu pihak pada data postes.

\section{HASIL dan PEMBAHASAN}

Sebelum dilakukan perlakuan pada penelitian terlebih dahulu diberikan tes pendahuluan untuk mengetahui kemampuan awal siswa pada kedua kelompok sampel diperoleh nilai rata-rata pretes siswa di kelas eksperimen 32,18 dengan simpangan baku 9,49 dan nilai rata-rata pretes pada kelas 
kontrol adalah 31,18 dengan simpangan baku 10,96. Perbandingan nilai pretes pada kelas eksperimen dan kelas kontrol dapat dilihat dalam bentuk grafik batang ditunjukkan pada Gambar 1:

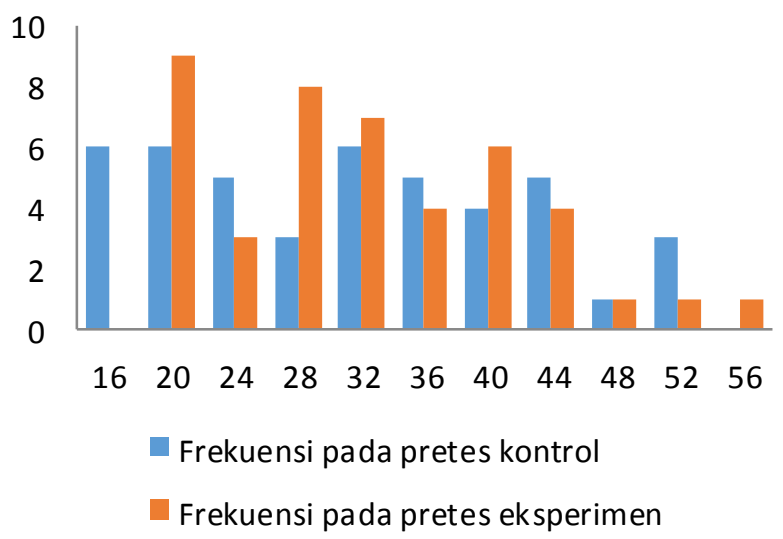

Setelah Kedua Sampel diterapkan perlakuan yang berbeda dimana pada kelompok kelas eksperimen diterapkan model pembelajaran kooperatif NHT (Numbered Head Together) berbantuan Mind Mapping dan pada kelompok kelas kontrol diterapkan model pembelajaran langsung diperoleh hasil postes kedua kelas yaitu: pada kelompok kelas Eksperimen rata- rata 73,18 dengan simpangan baku 10,37 dan pada kelompok kelas kontrol rata- rata 56,54 dengan simpangan baku 11,94. Grafik Batang Data Nilai Posest kedua kelas dapat dilihat pada Gambar 2 sebagai berikut:

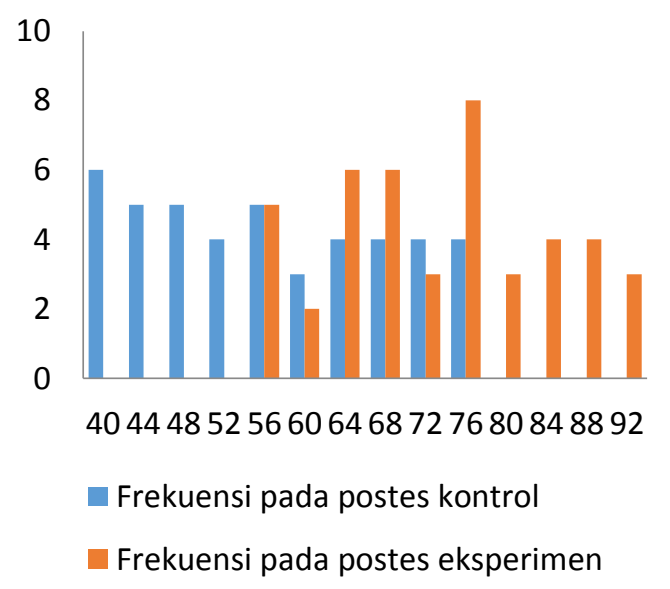

Dari hasil analisis data pretes kelompok siswa kelas eksperimen diperoleh $\mathrm{L}_{0} 0,1245$ $<$ Ltabel 0,1336 dan data pretes kelompok siswa kelas kontrol $\mathrm{L}_{0}=0,1023<_{\text {Ltabel }} 0,1336$. Sehingga disimpulkan bahwa kedua sampel berasal dari populasi yang berdistribusi normal karena $\mathrm{L}_{\text {hitung }}<\mathrm{L}_{\text {tabel }}$ pada taraf nyata $\alpha=0$, Dari hasil analisis data uji homogenitas dari pretes adalah homogeny karena kedua varians $F_{\text {hitung }}=1,34<$ $\mathrm{F}_{\text {tabel }}=1,67$. Pengujian kemampuan awal menggunakan uji t dua pihak. Dari hasil perhitungan diperoleh $\mathrm{t}_{\text {hitung }}=0,49$ sedangkan harga $t_{\text {tabel }}=1,99$ dengan taraf signifikan $\alpha=0,05$ dan derajat kebebasan $(\mathrm{dk})=\left(\mathrm{n}_{1}+\mathrm{n}_{2}-2\right)=(44+44-2)=86$. Berdasarkan perbandingan harga $\mathrm{t}$ di atas ,dimana $t_{\text {hitung }}<t_{\text {tabel }}(0,49<1,99) \quad$ dapat disimpulkan bahwa kelompok kelas eksperimen dan kelompok kelas kontrol mempunyai kemampuan yang samahipotesis Ha jika $t_{\text {hitung }} \leq \mathrm{t}_{1-\alpha}$ dengan $\mathrm{t}_{1-\alpha}$ didapat dari daftar distribusi $t$ dengan peluang $1-\alpha$ dimana $\alpha=0,05$ dan $\mathrm{dk}=\mathrm{N}_{1}+\mathrm{N}_{2}-2$ untuk $t_{\text {hitung }}>t_{1-\alpha}$, hipotesis Ha diterima. Dari hasil uji t satu pihak (postes) di kelas eksperimen dan kelas kontrol diperoleh $\mathrm{t}_{\text {hitung }}$ 7,44. Pada taraf signifikan $\alpha=0,05$ dan $\mathrm{dk}=86$, diperoleh $t_{\text {tabel }}=1,67$. Karena $t_{\text {hitung }}>t_{\text {tabel }}$ $(7,44>1,67)$, hal ini menunjukkan bahwa $\mathrm{H}_{\mathrm{a}}$ diterima dan $\mathrm{H}_{0}$ ditolak. Maka dapat disimpulkan bahwa ada pengaruh yang signifikan Model Pembelajaran Kooperatif NHT (Numbered Head Together) Berbantuan Mind Mapping Terhadap Hasil Belajar Fisika pada Materi Pokok Listrik Dinamis

Hasil penelitian menunjukkan bahwa kelompok siswa yang diajar dengan menggunakan model pembelajaran Kooperatif NHT (Numbered Head Together) Berbantuan Mind Mapping memperoleh hasil belajar yang lebih tinggi dibandingkan dengan kelompok siswa yang diajar dengan menggunakan model pembelajaran langsung Pada Materi Pokok Listrik Dinamis. Hal ini diperkuat dengan perolehan nilai rata- rata pretes kelompok siswa di kelas Eksperimen sebesar 32,18 dengan standar deviasi 9,49 dan nilai rata - rata pretes kelompok siswa di kelas kontrol 31,18 dengan standar deviasi 10,96. Hasil perhitungan uji t dua pihak diperoleh $t_{\text {hitung }}=0,49$ dan $t_{\text {tabel }}=1,99$ 
sehingga $t_{\text {hitung }}<t_{\text {tabel }}(0,49<1,99)$, hal ini menunjukkan bahwa kemampuan awal kelas eksperimen dan kelas kontrol adalah sama.

Selanjutnya kedua sampel diberikan perlakuan yang berbeda yaitu pada kelas eksperimen dengan menggunakan model pembelajaran kooperatif NHT (Numbered Head Together) Berbantuan Mind Mapping sedangkan kelas kontrol menggunakan model pembelajaran langsung. Dalam kegiatan belajar dengan menggunakan model pembelajaran Kooperatif NHT (Numbered Head Together) Berbantuan Mind Mapping siswa lebih tertarik dan semangat dalam belajar sehingga tujuan pembelajaran dapat tercapai.

Pada kelas kontrol kegiatan belajar mengajar menggunakan model pembelajaran langsung, dimana guru berperan aktif dalam menyampaikan materi pembelajaran dengan menggunakan beberapa tanya jawab. Secara keseluruhan pada pembelajaran langsung terdapat sebagian siswa yang mau menjawab pertanyaan yang diberikan oleh guru, sedangkan siswa masih kurang aktif dalam menyampaikan pendapat atau pertanyaan.

Setelah dilakukan pembelajaran, peneliti memberikan postes kepada kedua sampel. Dari nilai postes kedua sampel terlihat adanya peningkatan hasil belajar pada siswa, dimana nilai rata-rata postes kelompok siswa kelas eksperimen 73,18 sedangkan nilai rata-rata postes kelompok siswa kelas kontrol adalah 56,54 dari hasil perhitungan uji $\mathrm{t}$ satu pihak diperoleh $\mathrm{t}_{\text {hitung }}=$ 7,44 pada taraf nyata $\alpha=0,05$ dan $\mathrm{t}_{\text {tabel }}=$ 1,67. Berdasarkan temuan peneliti dan pengajuan hipotesis diperoleh bahwa siswa yang diajar menggunakan model pembelajaran kooperatif NHT (Numbered Head Together) berbantuan Mind Mapping terbukti ada pengaruh yang signifikan terhadap hasil belajar siswa.

Selama penelitian dilapangan, ada kelebihan-kelebihan yang peneliti temukan selama pembelajaran menggunakan model pembelajaran Kooperatif NHT (Numbered Head Together) Berbantuan Mind Mapping pada materi pokok listrik dinamis. Adapun kelebihannya antara lain:

1. Malatih siswa untuk saling klerjasama untuk menyelesaikan tugas kelompok
2. Siswa lebih mengingat pelajaran dengan melaksanakan eksperimen sesuai dengan Mind Mapping yang diberikan guru dan mengerjakannya secara berkelompok

3. Dengan pemberian penghargaan yang membuat siswa termotivasi dalam proses pembelajaran

4. Siswa akan lebih semangat dalam belajar karena mereka terpancing dengan memunculkan ide-ide kreatif mereka dengan tidak merasa takut dalam mengutarakannya baik lewat demonstrasi/eksperimen maupun lewat karya yang mereka buat.

\section{SIMPULAN dan SARAN}

Berdasarkan hasil penelitian dan pembahasan, disimpulkan bahwa Hasil belajar siswa yang diajar dengan menggunakan model Pembelajaran Kooperatif NHT (Numbered Head Together) berbantuan Mind Mapping pada materi pokok Listrik Dinamis diperolehan nilai rata-rata 73,18 dan hasil belajar siswa yang diajar dengan menggunakan model Pembelajaran Langsung diperolehan nilai rata-rata 56,54. Ada pengaruh yang signifikan Model Pembelajaran Kooperatif NHT (Numbered Head Together) Berbantuan Mind Mapping Terhadap Hasil Belajar Fisika pada Materi Pokok Listrik Dinamis Berdasarkan hasil (uji t satu pihak) diperoleh $t_{\text {hitung }}=7,44$ sedangkan $t_{\text {tabel }}=1,67$ $\left(t_{\text {hitung }}>t_{\text {tabel }}\right)$. Selain itu ada beberapa saran yang diajukan oleh peneliti, antara lain : Bagi siswa, agar melakukan persiapan belajar dan lebih aktif dalam setiap kegiatan pembelajaran agar memperoleh hasil yang lebih baik. Bagi guru, khususnya guru fisika diharapkan untuk menggunakan model pembelajaran yang dapat melibatkan keaktifan siswa dalam belajar, salah satunya dengan menerapkan Model Pembelajaran Kooperatif NHT (Numbered Head Together) berbantuan Mind Mapping. Bagi peneliti selanjutnya yang ingin meneliti Model Pembelajaran Kooperatif NHT (Numbered Head Together) berbantuan Mind Mapping disarankan melakukan penelitian pada lokasi dan materi yang berbeda, serta terlebih dahulu memperhatikan kelemahankelemahan dalam penelitian ini untuk dapat 
mencapai peningkatan hasil belajar yang lebih baik.

\section{DAFTAR PUSTAKA}

Antoro, Siswanto, Dwi. 2015. Penerapan Model Pembelajaran Kooperatif Tipe Numbered Head Together (NHT) dengan Media LKS untuk Meningkatkan Hasil Belajar Siswa Kelas V SDN Manukan Kulon Surabaya. Jurnal Pendidikan Dasar Pascasarjana Universitas Negeri Surabaya ISSN: 2477-1317.

Arikunto, Suharsimi. 2012. Dasar-Dasar Evaluasi Pendidikan: Edisi 2. Jakarta: Bumi Aksara.

Hutahaean, Juniar., dan Ratna, Salwa, Dwi. 2014. Pengaruh Model Pembelajaran Kooperatif Tipe Numbered Head Together (NHT) dengan Menggunakan Media Mind Mapping Terhadap Hasil Belajar Siswa Kelas XI Semester 2 Pada Materi Pokok Fluida Statis Di SMA Negeri 10 Medan TP. 2013/2014. Jurnal Inpafi: Universitas Negeri Medan Vol.2, No.4 Th 2014.

Karmila., Nurjannah., dan Kade, Amiruddin. Pengaruh Model Pembelajaran Kooperatif Tipe NHT (Numbered Head Together) dengan Metode Snowball Throwing Terhadap Hasil Belajar Siswa pada Materi Kalor Di Kelas X SMA Negeri 2 Bangkalan. Jurnal Pendidikan Fisika, Universitas Negeri Surabaya.

Ngalimun. 2012. Strategi dan Model Pembelajaran. Banjarmasin: Aswaja Pressindo.

Rusman. 2014. Model-Model Pembelajaran: Mengembangkan Profesionalisme Guru. Jakarta: Rajawali Pers.

Shoimin, Aris. 2014. 68 Model Pembelajaran Inovatif dalam Kurikulum 2013. Yogyakarta: Ar- Ruzz Media.

Siregar, Wasi, Rahmad., Djamas, Djusmaini., dan Nurhayati. 2013. Pengaruh Model Pembelajaran Kooperatif Tipe Numbered Head Together Berbantuan Handout Terhadap Hasil Belajar Fisika Siswa
Kelas XI IPA SMAN 7 Padang. Jurnal Pendidikan Fisika, FMIPA Universitas Negeri Padang Vol.1 Th 2013.

Slameto. 2010. Belajar dan Faktor-Faktor yang Mempengaruhi. Jakarta: Rineka Cipta.

Sudjana. 2005. Metoda Statistika. Bandung: Tarsito.

Sunardi, dkk. 2012. Fisika: Berbasis Pendidikan Karakter Bangsa Untuk SMA/MA Kelas XI. Bandung: Srikandi Empat Widya Utama.

Sutikno, Sobry. 2014. Metode \& ModelModel Pembelajaran: Menjadikan Proses Pembelajaran Lebih Variatf, Aktif, Inovatif, Efektif dan Menyenangkan. Lombok: Holistica.

Trianto. 2009. Mendesain Model Pembelajaran Inovatif-Progresif: Konsep, Landasan, dan Implementasinya pada KTSP. Jakarta: Prenada Media. 